\title{
Pengaruh Pengendalian Internal Pada Efisiensi Kredit Di Lembaga Perkreditan Desa (LPD) Se-Kecamatan Sukawati Kabupaten Gianyar
}

\author{
Kadek Ari Dyah Wilatini ${ }^{1}$ \\ Made Gede Wirakusuma ${ }^{2}$ \\ ${ }^{1,2}$ Fakultas Ekonomi dan Bisnis Universitas Udayana (Unud), Bali, Indonesia \\ e-mail: wilatini@yahoo.co.id
}

\begin{abstract}
ABSTRAK
Penelitian ini bertujuan untuk membuktikan secara empiris pengaruh unsur - unsur pengendalian internal pada efisiensi penyaluran kredit di LPD Kecamatan Sukawati, Kabupaten Gianyar. Data yang digunakan dalam penelitian ini adalah data primer berupa jawaban kuesioner dan data sekunder berupa non performing loan LPD. Pengambilan sampel menggunakan teknik sampel jenuh. Sampel yang digunakan sebanyak 33 LPD di Kecamatan Sukawati. Teknik analisis yang digunakan dalam penelitian ini adalah regresi linier berganda. Hasil analisis adalah lingkungan pengendalian, penilaian risiko, aktivitas pengendalian, dan pemantauan berpengaruh positif pada efisiensi penyaluran kredit, sedangkan informasi dan komunikasi berpengaruh negatif pada efisiensi penyaluran kredit. Kata kunci: Pengendalian internal, efisiensi penyaluran kredit, LPD.
\end{abstract}

\begin{abstract}
The purpose of this research was to obtain empirical evidence of the influence of internal control elements on the efficiency of lending in the LPD of Sukawati district, Gianyar Regency. The data used in this research are primary in the form of questionnaire answers and secondary data in the form of non performing loan. The sampling uses a saturated sample technique. The sample used was 33 LPDs in Sukawati district. The analysis technique used was multiple linier regression. Based on analysis concluded that environment control, risk assessment, control activities, and monitoring have a positive effect on the lending efficiency, while the information and communication has negative effect on lending efficiency.
\end{abstract}

Keyword: Internal control, lending efficiency, LPD.

\section{PENDAHULUAN}

LPD (Lembaga Perkreditan Desa) merupakan lembaga keuangan yang beroperasi di desa dan memiliki tugas memberdayakan masyarakat desa untuk meningkatkan perekonomian. Pemerintah Provinsi Bali melalui Surat Gubernur Nomor: 972 Tahun 1984, tertanggal 1 November 1984, tentang Lembaga Perkreditan Desa (LPD) mencetuskan gagasan pembentukan LPD pada setiap desa adat pakraman. Fungsi Lembaga Perkreditan Desa adalah untuk meniadakan praktik ijon dan gadai gelap, melancarkan lalu lintas uang, memberikan kesempatan berusaha bagi para warga desa,serta sekaligus menampung 
tenaga kerja yang ada di pedesaan (Suartana, 2009). LPD dalam melakukan kegiatan operasionalnya, memiliki tujuan utama yaitu menciptakan kemakmuran untuk krama desa dan dapat mencapai tingkat profitabilitas yang maksimal (Trisnawati \& Wirakusuma, 2015). Usaha pokok LPD yaitu menghimpun dana dalam bentuk tabungan (dhana sepelan) dan deposito (dhana sepepelan) yang kemudian disalurkan kembali kepada masyarakat dalam bentuk pinjaman atau kredit.

LPD merupakan pilihan utama bagi masyarakat untuk mendapatkan kredit atau pinjaman dana dengan prosedur yang mudah (Pramesti et al., 2015). Kredit merupakan suatu kegiatan operasional yang memiliki peranan paling besar dalam menyumbangkan pendapatan bagi LPD. Penyaluran kredit kepada masyarakat akan memberikan pendapatan bunga yang tinggi bila LPD mampu memberikan penyaluran dana yang besar kepada masyarakat. Selain memberikan pendapatan yang cukup besar, kredit memiliki risiko paling tinggi yang dapat memengaruhi tingkat kesehatan lembaga keuangan tersebut (Firdaus \& Ariyanti, 2008). Risiko kredit adalah risiko kredit yang tidak tertagih dikarenakan adanya suatu tenggang waktu pengembalian atau jangka waktu (Kasmir, 2008:75).

Pada penelitian Wiradana et al. (2015), menjelaskan kasus yang terjadi di LPD Poh Bergong, Desa Poh Bergong, Kabupaten Buleleng. Seorang warga yang bekerja sebagai pencari rongsokan dan ingin meminjam uang di LPD dengan menjadikan rumahnya sebagai jaminan. Ketika dimintai sertifikat oleh pihak LPD, warga tersebut beralasan sertifikat rumah merupakan warisan sehingga masih dalam proses. Maka dari itu LPD mengambil jalan tengah dengan membuat surat perjanjian untuk jaminan dan memberikan bantuan kreditnya. Namun setelah berjalan beberapa bulan, terjadilah tunggakan dan LPD akhirnya menuntut 
jaminan yang terlah dijaminkan. Setelah diselidiki, diketahuilah bahwa rumah tersebut sudah dimiliki oleh pihak lain, dan pihak yang melakukan pinjaman merupakan orang yang bertugas sebagai penjaga rumah pemilik sebenarnya.

Efisiensi penyaluran kredit digunakan untuk mengukur sampai sejauh mana kemampuan LPD dalam meningkatkan perolehan laba melalui pengelolaan sumber daya manusianya khususnya dari bagian kredit. Menurut Mahsun (2009), efisiensi merupakan pencapaian output tertentu dengan menggunakan input yang terendah berdasarkan target yang telah ditetapkan sebelumnya. Efisien tidaknya kredit disalurkan LPD dihitung menggunakan NPL (Non Performing Loan). Rasio ini menunjukkan total kredit bermasalah dengan total kredit yang dikeluarkan LPD (Almilia \& Herdinigtyas, 2005). Semakin tinggi rasio ini maka akan semakin buruk kualitas kredit LPD yang menyebabkan jumlah kredit bermasalah semakin besar. Peningkatan NPL akan sangat berdampak pada kelangsungan usahanya, semakin tinggi NPL menunjukkan rendahnya kemampuan LPD mencapai output yang ditargetkan. Salah satu langkah yang dapat dilakukan pihak LPD adalah menerapkan struktur pengendalian internal yang efisien. Pengendalian internal yang efisien dapat meminimalisir terjadinya kredit macet dan sebagai dasar kegiatan operasional yang sehat dan aman sehingga dapat dipercaya oleh masyarakat (Ariesa \& Berasategu, 2009).

- Kabupaten Gianyar memiliki 270 LPD dengan 33 LPD berada di Kecamatan Sukawati. Kecamatan Sukawati memiliki potensi dalam bidang kerajinan seni yang banyak diperdagangkan tidak hanya di Bali tetapi juga di luar Bali. Potensi ini menyebabkan banyak masyarakat yang melirik peluang untuk 
membuka usaha, seperti artshop sehingga dibutuhkan sumber pembiayaan yang memudahkan masyarakat dalam membuka usaha, dan LPD memiliki peran yang sangat penting bagi desa adat pakramannya. LPD se - Kecamatan Sukawati dipilih karena dalam empat tahun periode 2014 hingga 2017 terjadi peningkatan rasio NPL, dimana NPL (Non Performing Loan) merupakan ukuran kredit bermasalah yang dihitung dengan perbandingan dari jumlah kredit yang tidak lancar (kredit kurang lancar, kredit diragukan, dan kredit macet) dibagi jumlah kredit yang disalurkan. Berdasarkan Surat Edaran Bank Indonesia Nomor 3/30/DPNP tangal 14 Desember 2001 batas maksimal untuk rasio NPL adalah sebesar 5\%, pada Tabel 1 menunjukkan bahwa tahun 2016 dan 2017 terhitung melebihi batas maksimal untuk NPL. Semakin besar tingkat NPL, menunjukkan bahwa lembaga keuangan tersebut tidak profesional dalam pengelolaan kreditnya (RMP et al., 2014).

Tabel 1.

Perhitungan Non Performing Loan (NPL) pada Lembaga Perkreditan Desa se-Kecamatan Sukawati Periode Tahun 2014 - 2017 (dalam Ribuan Rupiah)

\begin{tabular}{lrrrr}
\hline \multirow{2}{*}{ Uraian } & \multicolumn{4}{c}{ Tahun } \\
\cline { 2 - 5 } & \multicolumn{1}{c}{2014} & \multicolumn{1}{c}{2015} & \multicolumn{1}{c}{2016} & \multicolumn{1}{c}{2017} \\
\hline Kredit Kurang Lancar & 6.309 .629 & 8.270 .584 & 9.971 .484 & 13.041 .760 \\
Kredit Diragukan & 4.061 .102 & 4.452 .955 & 5.286 .469 & 7.346 .379 \\
Kredit Macet & 3.739 .961 & 4.233 .219 & 7.406 .388 & 9.399 .275 \\
Pinjaman Yang Diberikan & 327.596 .391 & 357.547 .516 & 420.965 .614 & 472.913 .352 \\
Rasio NPL & $4.3 \%$ & $4.7 \%$ & $5.3 \%$ & $6.2 \%$ \\
\hline Sumber : LPLPD Gianyar, data diolah (2018) & &
\end{tabular}

Penerapan komponen pengendalian internal dalam proses kegiatan LPD dilakukan untuk memberikan kebijakan dan prosedur yang sistematis dalam penyaluran kredit. LPD perlu memberikan penilaian serta merasa yakin bahwa nasabahnya mampu mengembalikan kredit yang diterimanya setelah kredit tersebut diajukan. Tidak berjalannya fungsi dan proses pengendalian internal 
dalam suatu organisasi merupakan salah satu penyebab timbulnya berbagai macam tindak kecurangan di lingkungan organisasi tersebut, oleh karena itu sistem pengendalian internal memegang peranan yang cukup penting dalam menjaga keamanan aset entitas dari tindak pencurian, penyalahgunaan wewenang, maupun korupsi.

Jensen \& Meckling (1976) menjelaskan hubungan keagenan di dalam teori agensi (agency theory) bahwa perusahaan merupakan kumpulan kontrak antara pemilik sumber daya ekonomi dan manajer yang mengurus penggunaan dan pengendalian sumber daya tersebut. Menurut Messier et al., (2006), hubungan keagenan ini mengakibatkan dua permasalahan yaitu terjadinya informasi asimetris, dimana manajemen secara umum memiliki lebih banyak informasi mengenai posisi keuangan yang sebenarnya. Kedua terjadinya konflik kepentingan akibat ketidaksamaan tujuan, dimana manajemen tidak selalu bertindak sesuai kepentingan pemilik.

LPD dikelola secara terpisah dengan krama desa sehingga memungkinkan terjadinya konflik keagenan (Setyawan \& Putri, 2013). Teori ini terkadang menimbulkan suatu permasalahan yang diakibatkan oleh para pelaku yang memiliki kepentingan yang berbeda. Dalam pemberian kredit dapat terjadi konflik kepentingan antara principal (pihak LPD) dan agent (debitur), dimana debitur tidak menjalankan kewajibannya sesuai dengan perjanjian kepada pihak LPD dan hal ini berdampak pada profitabilitas dan kelangsungan usaha LPD. Dalam hal ini pengelolaan lembaga keuangan perlu diawasi dan dikendalikan untuk memastikan 
bahwa pengelolaan telah dilakukan berdasarkan peraturan dan ketentuan yang berlaku (Safitri, 2011).

Pengendalian internal adalah suatu kebutuhan, karena tanpa hal tersebut suatu entitas tidak akan mampu menjalankan kegiatan operasi dengan normal dan baik (Takahiro \& Jia, 2012). Pengendalian internal adalah suatu proses yang dipengaruhi oleh sumber daya manusia dan sistem teknologi informasi yang dirancang untuk membantu organisasi mencapai suatu tujuan tertentu. Pengendalian internal merupakan suatu cara untuk mengarahkan, mengawasi, dan mengukur sumber daya suatu organisasi, serta berperan penting dalam pencegahan dan pendeteksian penggelapan (fraud).

Pengendalian internal didefinisikan oleh Committee of Sponsoring Organization (COSO) sebagai suatu proses yang dipengaruhi oleh manajemen dalam organisasi atau perushaan yang digunakan sebagai dasar untuk mencapai tujuan perusahaan (Janvrin et al., 2012). Lima komponen dari struktur pengendalian internal antara lain: (1) lingkungan pengendalian, (2) penilaian risiko, (3) aktivitas pengendalian, (4) informasi dan komunikasi, dan (5) pemantauan.

Lingkungan pengendalian merupakan dasar semua komponen pengendalian internal, menyediakan disiplin dan struktur suatu organisasi (Halim, 2008:212). Lingkungan pengendalian menentukan arah perusahaan dan mempengaruhi kesadaran pengendalian pihak manajemen dan karyawan. Lingkungan pengendalian terdiri dari faktor - faktor seperti integritas dan nilai etika, komitmen terhadap kompetensi, filosofi dan gaya operasi manajemen, 
struktur organisasi, penetapan wewenang dan tanggung jawab, dan kebijakan serta praktik sumber daya manusia. Lingkungan pengendalian pada Lembaga Perkreditan Desa (LPD) merupakan gambaran mengenai sikap dan kesadasaran secara menyeluruh dari pengurus, karyawan, dan badan pengawas internal mengenai pentingnya pengendalian internal organisasi LPD. Berdasarkan jawaban responden dari hasil penelitian yang dilakukan Virnawan \& Putra (2014), Suriadnya \& Sunarwijaya (2015), Ekaulandari \& Dwirandra (2013) dan Gunadi et al. (2017) menunjukkan bahwa lingkungan pengendalian berpengaruh positif terhadap efisiensi penyaluran kredit. Sedangkan Penelitian Febrianti (2012) menunjukkan bahwa lingkungan pengendalian tidak berpengaruh positif.

$\mathrm{H}_{1}$ : Lingkungan pengendalian berpengaruh positif pada efisiensi penyaluran kredit di LPD di Kecamatan Sukawati, Kabupaten Gianyar.

Penilaian risiko adalah identifikasi entitas dan analisis terhadap risiko yang relevan untuk mencapai tujuannya, membentuk suatu dasar untuk menentukan bagaimana risiko harus dikelola (Halim, 2008:213). Boynton et al., 2009:383) menyatakan penilaian risiko untuk tujuan pelaporan keuangan adalah identifikasi, analisis, dan pengelolaan risiko suatu entitas yang relevan dengan penyusunan laporan keuangan yang disajikan secara wajar sesuai dengan prinsip prinsip akuntansi yang berlaku secara umum.Penilaian risiko LPD tidak hanya menyangkut ketaatan terhadap metode pelaporan, tetapi lebih luas meliputi risiko usaha yang dihadapi oleh LPD (Suartana, 2009). Hasil penelitian yang dilakukan Virnawan \& Putra (2014), Ekaulandari \& Dwirandra (2013), dan Gunadi et al. (2017) menyatakan bahwa penilaian risiko memiliki pengaruh yang positif pada 
efisiensi penyaluran kredit. Sementara hasil dari penelitian Suriadnya \& Sunarwijaya (2015) dan Febriani (2016) menyatakan berpengaruh negatif.

$\mathrm{H}_{2}$ : Penilaian risiko berpengaruh positif pada efisiensi penyaluran kredit di LPD di Kecamatan Sukawati, Kabupaten Gianyar.

Boynton et al. (2009:364) menyatakan bahwa sistem informasi dan komunikasi terdiri dari metode dan catatan yang diciptakan untuk mengidentifikasi, mengumpulkan, menganalisis, mengklasifikasi, mencatat, dan melaporkan transaksi - transaksi entitas untuk memelihara akuntabilitas dari aktiva dan kewajiban yang berhubungan. Hasil penelitian yang dilakukan Virnawan \& Putra (2014) dan Ekaulandari \& Dwirandra (2013) menyatakan sistem akuntansi yang termasuk dalam variabel informasi dan komunikasi berpengaruh positif terhadap efisiensi penyaluran kredit sementara hasil penelitian Suriadnya \& Sunarwijaya (2015), Gunadi et al. (2017) dan Febriani (2016) menyatakan tidak berpengaruh.

$\mathrm{H}_{3}$ : Informasi dan komunikasi berpengaruh positif pada efisiensi penyaluran kredit di LPD di Kecamatan Sukawati, Kabupaten Gianyar.

Aktivitas pengendalian adalah kebijakan dan prosedur yang membantu menjamin bahwa arahan manajemen dilaksanakan. Menurut Suartana (2009) aktivitas pengendalian dapat dilakukan dengan kegiatan - kegiatan seperti telaah kinerja, pengelolan informasi, pengendalian fisik, dan pemisahan fungsi. Hasil penelitian yang dilakukan Virnawan \& Putra (2014), Ekaulandari \& Dwirandra (2013), dan Gunadi et al. (2017) menunjukan bahwa aktivitas pengendalian berpengaruh positif terhadap efisiensi penyaluran kredit. Sementara hasil dari 
penelitian Suriadnya \& Sunarwijaya (2015) dan Febriani (2016)menyatakan tidak berpengaruh.

$\mathrm{H}_{4}$ : Aktivitas pengendalian berpengaruh positif pada efisiensi penyaluran kredit di LPD se-Kecamatan Sukawati, Kabupaten Gianyar.

Pemantauan adalah suatu proses yang menilai kualitas kinerja pengendalian internal pada suatu waktu. Pemantauan melibatkan penilaian rancangan dan pengoperasian pengendalian dengan dasar waktu dan mengambil tindakan perbaikan yang diperlukan (Boynton et al., 2009:400). Hasil penelitian yang dilakukan oleh Virnawan \& Putra (2014) dan Ekaulandari \& Dwirandra (2013) menyatakan bahwa pemantauan tidak berpengaruh sementara Febriani (2016) dan Gunadi et al. (2017) menyatakan bahwa pemantauan berpengaruh positif pada efisiensi penyaluran kredit.

$\mathrm{H}_{5}$ : Pemantauan berpengaruh positif pada efisiensi penyaluran kredit di LPD se- Kecamatan Sukawati, Kabupaten Gianyar.

\section{METODE PENELITIAN}

Penelitian ini menggunakan pendekatan kuantitatif yang berbentuk asosiatif. LPD se-Kecamatan Sukawati, Kabupaten Gianyar dipilih sebagai lokasi penelitian. Variabel - variabel yang digunakan meliputi variabel dependen yaitu efisiensi penyaluran kredit (Y) dan variabel independen yaitu lingkungan pengendalian $\left(\mathrm{X}_{1}\right)$, penilaian risiko $\left(\mathrm{X}_{2}\right)$, informasi dan komunikasi $\left(\mathrm{X}_{3}\right)$, aktivitas pengendalian $\left(\mathrm{X}_{4}\right)$, dan pemantauan $\left(\mathrm{X}_{5}\right)$. Populasi dalam penelitian adalah Pengawas Internal, Kepala LPD, dan bagian kredit. Data dari LPLPD (Lembaga Pemberdayaan Lembaga Perkreditan Desa) Kabupaten Gianyar terdapat 33 LPD. Teknik perolehan sampel mengunakan sampel jenuh dan diperoleh 99 sampel. Metode 
pengumpulan data menggunakan metode survei dengan teknik kuesioner dan jumlah kuesioner kembali sebanyak 93 kuesioner.

Penelitian ini mengulas pengaruh lingkungan pengendalian, penilaian risiko, informasi dan komunikasi, aktivitas pengendalian, dan pemantauan pada efisiensi penyaluran kredit di LPD Kecamatan Sukawati, Kabupaten Gianyar. Secara sistematis, model penelitian yang digunakan adalah sebagai berikut.

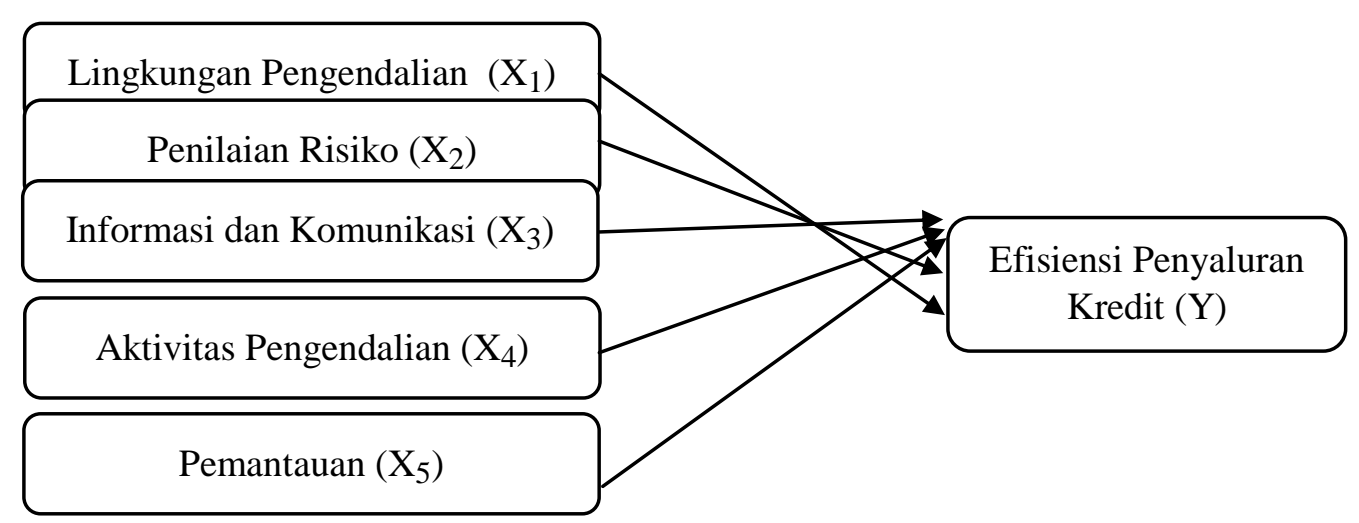

Sumber : Data diolah, 2018

\section{Gambar 1. Model Penelitian}

Analisis regresi berganda digunakan sebagai teknik analisis data dalam penelitian. Analisis data berpedoman pada hasil kuesioner yang diukur menggunakan skala likert 4 poin. Tahapan analisis terdiri dari (1) uji asumsi klasik meliputi uji normalitas, uji multikolinearitas, dan uji heterokedastisitas, (2) statistik deskriptif, (3) analisis regresi linier berganda, (4) pengujian hipotesis meliputi uji koefisien determinasi $\left(\mathrm{R}^{2}\right)$, uji statistik F (uji kelayakan model) dan uji statistik t (uji hipotesis). Analisis regresi linier berganda digunakan untuk melihat pengaruh variable lingkungan pengendalian, penilaian risiko, informasi dan komunikasi, aktivitas pengendalian, dan pemantauan pada efisiensi 
penyaluran kredit, model persamaan analisis regresi linier berganda dalam penelitian ini adalah sebagai berikut.

$\mathrm{Y}=\alpha+\beta_{1} . \mathrm{X} 1+\beta_{2 .} \mathrm{X} 2+\beta_{3} . \mathrm{X} 3+\beta_{4} \mathrm{X} 4+\beta_{5} . \mathrm{X} 5+\mathrm{e}$

Keterangan :

$\mathrm{Y} \quad=$ Penyaluran Kredit

$\alpha \quad=$ Nilai Konstansa

$\beta_{1,}, \beta_{2}, \beta_{3}, \beta_{4}, \beta_{5}=$ Koefisien regresi variabel independen

$\mathrm{X} 1=$ Lingkungan Pengendalian

$\mathrm{X} 2=$ Penilaian Risiko

X3 = Informasi dan Komunikasi

X4 = Aktivitas Pengendalian

$\mathrm{X} 5 \quad=$ Pemantauan

$\mathrm{e}=$ error

\section{HASIL DAN PEMBAHASAN}

Kuesioner yang disebar dalam penelitian ini sebanyak 99 kuesioner untuk 33 LPD. Tingkat pengembalian responden yang dapat dianalisis sebesar 93,9 \%. Penelitian ini layak untuk dilanjutkan karena berdasarkan central limit theorem menyatakan bahwa jumlah minimal sampel untuk mencari kurva normal setidaknya mencapai nilai minimal yaitu 30 responden. Rincian mengenai pengiriman dan pengembalian kuesioner dapat dilihat pada Tabel 2 berikut. 
Tabel 2.

Rincian Pengiriman dan Pengembalian kuesioner

\begin{tabular}{lc}
\hline \multicolumn{1}{c}{ Keterangan } & Jumlah Kuesioner \\
\hline Kuesioner yang dibagi & 99 \\
Kuesioner yang tidak kembali & 6 \\
Kuesioner yang kembali & 93 \\
Kuesioner yang tidak lengkap & 0 \\
Kuesioner yang digunakan & 93 \\
Tingkat pengembalian kuesioner: & \\
$=93 / 99$ X 100\% & \\
$=93,9 \%$ & \\
Tingkat pengembalian yang digunakan: & \\
$=93 / 99$ X 100\% & \\
$=93,9 \%$ & \\
Sumber $:$ Data diolah, 2018 &
\end{tabular}

Sumber : Data diolah, 2018

Uji validitas adalah untuk mengukur sejauh mana ketepatan alat ukur penelitian tentang isi atau arti yang diukur (Sugiyono, 2017:267). Kuesioner dinyatakan valid jika pernyataan yang terdapat dalam kuesioner dapat mengukur apa yang ingin diukur oleh peneliti. Syarat minimum suatu kuesioner untuk memenuhi validitas adalah jika $r$ bernilai lebih besar dari 0,30 . Hasil uji validitas dapat dilihat pada Tabel 3 berikut. 
Tabel 3.

Hasil Uji Validitas

\begin{tabular}{|c|c|c|c|c|}
\hline No. & Instrumen & $\begin{array}{c}\text { Item } \\
\text { Pertanyaan }\end{array}$ & $\begin{array}{c}\text { Koefisien } \\
\text { Korelasi }\end{array}$ & Keterangan \\
\hline \multirow[t]{9}{*}{1.} & Lingkungan Pengendalian & $\mathrm{X} 1.1$ & 0,778 & Valid \\
\hline & & $\mathrm{X} 1.2$ & 0,702 & Valid \\
\hline & & $\mathrm{X} 1.3$ & 0,721 & Valid \\
\hline & & X1.4 & 0,828 & Valid \\
\hline & & $\mathrm{X} 1.5$ & 0,738 & Valid \\
\hline & & X1.6 & 0,784 & Valid \\
\hline & & $\mathrm{X} 1.7$ & 0,799 & Valid \\
\hline & & $\mathrm{X} 1.8$ & 0,822 & Valid \\
\hline & & X1.9 & 0,715 & Valid \\
\hline \multirow[t]{6}{*}{2.} & Penilaian Risiko & $\mathrm{X} 2.1$ & 0,896 & Valid \\
\hline & & $\mathrm{X} 2.2$ & 0,824 & Valid \\
\hline & & $\mathrm{X} 2.3$ & 0,800 & Valid \\
\hline & & X2.4 & 0,705 & Valid \\
\hline & & $\mathrm{X} 2.5$ & 0,792 & Valid \\
\hline & & $\mathrm{X} 2.6$ & 0,795 & Valid \\
\hline \multirow{4}{*}{3.} & Informasi Komunikasi & $\mathrm{X} 4.1$ & 0,870 & Valid \\
\hline & & $\mathrm{X} 4.2$ & 0,850 & Valid \\
\hline & & $\mathrm{X} 4.3$ & 0,862 & Valid \\
\hline & & $\mathrm{X} 4.4$ & 0,908 & Valid \\
\hline \multirow[t]{6}{*}{4.} & Aktivitas Pengendalian & X3.1 & 0,833 & Valid \\
\hline & & $\mathrm{X} 3.2$ & 0,622 & Valid \\
\hline & & X3.3 & 0,750 & Valid \\
\hline & & X3.4 & 0,817 & Valid \\
\hline & & X3.5 & 0,890 & Valid \\
\hline & & X3.6 & 0,831 & Valid \\
\hline \multirow[t]{6}{*}{5.} & Pemantauan & X5.1 & 0,895 & Valid \\
\hline & & $\mathrm{X} 5.2$ & 0,812 & Valid \\
\hline & & X5.3 & 0,816 & Valid \\
\hline & & X5.4 & 0,864 & Valid \\
\hline & & $\mathrm{X} 5.5$ & 0,831 & Valid \\
\hline & & $\mathrm{X} 5.6$ & 0,845 & Valid \\
\hline \multirow[t]{4}{*}{6.} & Efisiensi Penyaluran Kredit & Y1.1 & 0,850 & Valid \\
\hline & & $\mathrm{Y} 1.2$ & 0,772 & Valid \\
\hline & & Y1.3 & 0,862 & Valid \\
\hline & & Y1.4 & 0,896 & Valid \\
\hline
\end{tabular}

Sumber: Data diolah, 2018

Berdasarkan Tabel 3 dapat dilihat bahwa koefisien korelasi dari masing masing pertanyaan dalam kuesioner lebih besar dari 0,30 sehingga dapat disimpulkan bahwa pernyataan dalam kuesioner telah memenuhi syarat validitas data.

Pengujian reliabilitas menunjukkan sejauh mana pengukuran dapat memberikan hasil konsisten bila dilakukan pengukuran kembali terhadap gejala 
yang sama (Sugiyono, 2017:267). Uji reliabilitas dihitung menggunakan uji statistik Cronbach Alpha. Jika hasil dari Cronbach Alpha menghasilkan nilai alpha diatas 0,70, maka instrumen yang digunakan dikatakan reliabel. Hasil uji reliabilitas dapat dilihat pada Tabel 4 berikut.

Tabel 4.

Hasil Uji Reliabilitas

\begin{tabular}{clcc}
\hline No. & \multicolumn{1}{c}{ Variabel } & Cronbach's Alpha & Keterangan \\
\hline 1. & Lingkungan Pengendalian & 0,912 & Reliabel \\
2. & Penaksiran Risiko & 0,887 & Reliabel \\
3. & Informasi dan Komunikasi & 0,893 & Reliabel \\
4. & Aktivitas Pengendalian & 0,869 & Reliabel \\
5. & Pemantauan & 0,919 & Reliabel \\
6. & Efisiensi Penyaluran Kredit & 0,864 & Reliabel \\
\hline
\end{tabular}

Sumber: Data diolah, 2018

Berdasarkan Tabel 4 dapat dilihat bahawa nilai Cronbach's Alpha masing - masing variabel memiliki nilai lebih besar dari 0,70. Hal ini menunjukkan bahwa semua pernyataan dalam kuesioner penelitian ini reliabel dan dapat digunakan.

Uji Normalitas bertujuan untuk menguji apakah dalam model regresi variabel terikat dan variabel bebas keduanya mempunyai distribusi normal atau tidak. Model regresi yang baik adalah memiliki distribusi normal mendekati normal (Ghozali, 2012:160). Untuk mendeteksi terpenuhi atau tidaknya uji normalitas, maka penelitian ini menggunakan uji Kolmogorov-Smirnov, dengan ketentuan bila signifikansi tiap variabel lebih besar dari 0,05 maka berdistribusi normal, sedangkan bila signifikansi variabel lebih kecil dari 0,05 maka data tidak berdistribusi normal. 
Tabel 5.

ISSN: 2302-8556

Hasil Uji Normalitas

Kolmogorov-Smirnov

$\mathrm{N}$

Vol.28.2.Agustus (2019): 874-902

Asymp.Sig(2-tailed)

0,950

Sumber: Data diolah, 2018

Berdasarkan pada Tabel 5 dapat dilihat signifikansi variabel bebas dan variabel terikat yaitu sebesar 0,950 lebih besar dari alpha $=0,05$ sehingga dapat disimpulkan data untuk variabel lingkungan pengendalian, penilaian risiko, informasi dan komunikasi, aktivitas pengendalian, pemantauan, dan efisiensi penyaluran kredit berdistribusi normal.

Uji Multikolinearitas bertujuan untuk menguji apakah model regresi ditemukan adanya korelasi antar variabel bebas, dengan kata lain tidak terjadi multikolinearitas. Model regresi yang bebas dari multikolinearitas adalah yang memiliki nilai Variance Inflation Factor (VIF) kurang dari 10 atau nilai tolerance lebih besar dari 0,1 (10\%). Multikolinearitas dapat dilihat dari hasil tolerance atau VIF yang disajikan dalam Tabel 6 berikut:

Tabel 6.

Hasil Uji Multikolinearitas

\begin{tabular}{lcc}
\hline \multicolumn{1}{c}{ Variabel } & Tolerance & VIF \\
\hline Lingkungan Pengendalian (X1) & 0,488 & 2,049 \\
Penilaian Risiko (X2) & 0,311 & 3,219 \\
Informasi dan Komunikasi (X3) & 0,711 & 1,407 \\
Aktivitas Pengendalian (X4) & 0,262 & 3,816 \\
Pemantauan (X5) & 0,261 & 3,833 \\
\hline
\end{tabular}

Sumber: Data diolah, 2018

Berdasarkan Tabel 6 menunjukkan bahwa seluruh variabel menunjukkan nilai tolerance lebih dari 0,1 (10 persen) dan nilai VIF yang kurang dari 10. Hal ini mengindikasikan bahwa variabel - variabel bebas yang digunakan dalam penelitian ini tidak terjadi multikolinearitas.

Uji heteroskedastisitas bertujuan untuk menguji apakah dalam model regresi terjadi ketidaksamaan hasil dari residual satu ke pengamatan ke 
pengamatan yang lain. Heteroskedastisitas diuji dengan menggunakan uji Glejser yaitu dengan cara meregresikan nilai absolute residual terhadap variabel independen. Jika tingkat signifikan berada di atas 0,05 maka model regresi ini bebas dari masalah heteroskedastisitas. Hasil uji heteroskedastisitas dapat dilihat pada Tabel 7 berikut.

Tabel 7.

Hasil Uji Heteroskedastisitas

\begin{tabular}{lcl}
\hline \multicolumn{1}{c}{ Model } & Sig (2-tailed) & Keterangan \\
\hline Lingkungan Pengendalian (X1) & 0,736 & Bebas Heteroskedastisitas \\
Penilaian Risiko (X2) & 0,265 & Bebas Heteroskedastisitas \\
Informasi dan Komunikasi (X3) & 0,145 & Bebas Heteroskedastisitas \\
Aktivitas Pengendalian (X4) & 0,827 & Bebas Heteroskedastisitas \\
Pemantauan (X5) & 0,162 & Bebas Heteroskedastisitas
\end{tabular}

Sumber: Data diolah, 2018

Berdasarkan Tabel 7 dapat dilihat bahwa variabel struktur pengendalian internal secara signifikan memengaruhi variabel efisiensi penyaluran kredit yang terlihat dari tingkat signifikansinya di atas 0,05 . Hal ini menunjukkan bahwa model regresi tidak mengandung adanya Heteroskedastisitas.

Statistik deskriptif adalah statistik yang digunakan untuk menganalisa data dengan cara mendeskripsikan atau menggambarkan data yang telah terkumpul sebagaimana adanya tanpa bermaksud membuat kesimpulan yang berlaku untuk umum atau generalisasi (Sugiyono, 2017:287). Hasil statistik deskriptif penelitian ini dapat dilihat pada Tabel 8 sebagai berikut. 
Tabel 8. Hasil Statistik Deskriptif

\begin{tabular}{lccccc}
\hline \multicolumn{1}{c}{ Variabel } & N & Min. & Max & Mean & $\begin{array}{c}\text { Standard } \\
\text { Deviasi }\end{array}$ \\
\hline Lingkungan Pengendalian (X1) & 93 & 2,33 & 4,00 & 3,42 & 0,47292 \\
Penilaian Risiko (X2) & 93 & 2,33 & 4,00 & 3,36 & 0,51651 \\
Informasi dan Komunikasi (X3) & 93 & 2,25 & 4,00 & 3,31 & 0,58091 \\
Aktivitas Pengendalian (X4) & 93 & 2,17 & 4,00 & 3,34 & 0,50202 \\
Pemantauan (X5) & 93 & 2,33 & 4,00 & 3,32 & 0,51990 \\
Efisiensi Penyaluran Kredit (Y) & 93 & 2,25 & 4,00 & 3,39 & 0,57654 \\
\hline$\quad$ Sumber: Data diolah, 2018 & & & & &
\end{tabular}

Variabel lingkungan pengendalian memiliki nilai minimum sebesar 2,33 persen dan nilai maksimum sebesar 4,00 persen dengan nilai rata - rata sebesar 3,42 persen. Nilai rata - rata ini menunjukkan bahwa responden dalam menjawab pernyataan kuesioner cenderung menilai variabel lingkungan pengendalian tinggi, yang mencerminkan lingkungan pengendalian LPD baik. Standar deviasi pada variabel lingkungan pengendalian sebesar 0,47 persen.

Variabel penilaian risiko memiliki nilai minimum sebesar 2,33 persen dan nilai maksimum sebesar 4,00 persen. Rata - rata variabel penilaian risiko sebesar 3,36 persen. Nilai rata - rata ini menunjukkan bahwa responden dalam menjawab pernyataan kuesioner cenderung menilai penilaian risiko tingi, yang mencerminkan penilaian risiko LPD baik. Standar deviasi pada variabel Penilaian Risiko sebesar 0,51 persen.

Variabel informasi dan komunikasi memiliki nilai minimum sebesar 2,25 persen dan nilai maksimum sebesar 4,00 persen. Rata - rata variabel informasi dan komunikasi sebesar 3,31 persen. Nilai rata - rata ini menunjukkan bahwa responden dalam menjawab pernyataan kuesioner cenderung menilai informasi dan komunikasi tinggi. 
Variabel aktivitas pengendalian memiliki nilai minimum sebesar 2,17 persen dan nilai maksimum sebesar 4,00 persen. Rata - rata variabel aktivitas pengendalian sebesar 3,34 persen. Nilai rata - rata ini menunjukkan bahwa responden dalam menjawab pernyataan kuesioner cenderung menilai aktivitas pengendalian tinggi, yang mencerminkan aktivitas pengendalian LPD baik.

Variabel pemantauan memiliki nilai minimum sebesar 2,33 persen dan nilai maksimum sebesar 4,00 persen. Rata - rata variabel pemantauan sebesar 3,32 persen. Nilai rata - rata ini menunjukkan bahwa responden dalam menjawab pernyataan kuesioner cenderung menilai pemantauan tinggi, yang mencerminkan pemantauan LPD baik. Variabel efisiensi penyaluran kredit memiliki nilai minimum sebesar 2,25 persen dan nilai maksimum sebesar 4,00 persen. Rata rata variabel efisiensi penyaluran kredit sebesar 3,39 persen. Standar deviasi pada variabel efisiensi penyaluran kredit sebesar 0,57 persen.

Analisis regresi linier berganda digunakan untuk mengetahui hubungan dan pengaruh variabel bebas terhadap variabel terikat. Regresi linier berganda mampu menjelaskan pengaruh pengendalian internal terhadap efisiensi penyaluran kredit pada LPD di Kecamatan Sukawati. Hasil pengujian analisis regresi linier berganda dapat dilihat pada Tabel 9 berikut. 
Tabel 9.

Hasil Uji Regresi Linier Berganda

\begin{tabular}{|c|c|c|c|c|c|}
\hline \multirow{2}{*}{ Model } & \multicolumn{2}{|c|}{$\begin{array}{c}\text { Unstandardized } \\
\text { Coefficients }\end{array}$} & \multirow{2}{*}{$\begin{array}{l}\text { Standardized } \\
\text { Coefficients } \\
\text { Beta }\end{array}$} & \multirow{2}{*}{$\mathrm{T}$} & \multirow{2}{*}{ Sig. } \\
\hline & $\mathrm{B}$ & $\begin{array}{l}\text { Std. } \\
\text { Error }\end{array}$ & & & \\
\hline (Constant) & 0,240 & 0,314 & & 0,764 & 0,447 \\
\hline Lingkungan Pengendalian & 0,229 & 0,071 & 0,188 & 3,234 & 0,002 \\
\hline Penilaian Risiko & 0,405 & 0,081 & 0,363 & 4,981 & 0,000 \\
\hline Informasi dan Komunikasi & $-0,154$ & 0,048 & $-0,156$ & $-3,232$ & 0,002 \\
\hline Aktivitas Pengendalian & 0,242 & 0,091 & 0,210 & 2,655 & 0,009 \\
\hline Pemantauan & 0,199 & 0,088 & 0,179 & 2,256 & 0,027 \\
\hline R Square & 0,857 & & & & \\
\hline Signifikansi F & 0,000 & & & & \\
\hline F Hitung & 104,042 & & & & \\
\hline
\end{tabular}

Berdasarkan Tabel 9, analisis regresi linier berganda terhadap variabel bebas dan variabel terikat diperoleh hasil koefisien $a=0,240$ dan nilai koefisien $\beta 1=0,229, \beta 2=0,405, \beta 3=-0,154, \beta 4=0,242, \quad \beta 5=0,199$.

Berdasarkan hasil penelitian, maka model persamaan regresi linier berganda tampak sebagai berikut:

$$
\mathrm{Y}=0,240-0,229 \mathrm{X}_{1}-0,405 \mathrm{X}_{2}+0,154 \mathrm{X}_{3}-0,0242 \mathrm{X}_{4}-0,199 \mathrm{X}_{5}
$$

Nilai koefisien beta dari variabel lingkungan pengendalian, penilaian risiko, aktivitas pengendalian, dan pemantauan bernilai positif yang berarti bahwa semakin tinggi variable tersebut, menyebabkan semakin meningkat efisiensi penyaluran kredit.

Nilai koefisien beta dari variabel informasi dan komunikasi bernilai negatif yang berarti bahwa semakin tinggi informasi dan komunikasi, menyebabkan menurunnya efisiensi penyaluran kredit. Nilai koefisien $\beta 3=-$ 0,154 menunjukkan jika informasi dan komunikasi meningkat, maka efisiensi akan menurun sebesar -0,156 dengan asumsi variabel independen lainnya konstan. 
Nilai konstanta sebesar 0,240 menunjukkan bahwa variabel lingkungan pengendalian, penilaian risiko, informasi dan komunikasi, aktivitas pengendalian, dan pemantauan sama dengan nol (tetap atau tidak berubah), menyebabkan efisiensi penyaluran kredit meningkat sebesar konstantanya.

Variabel penilaian risiko memiliki nilai koefisien beta standardized yang paling tinggi yaitu 0,363 . Hal tersebut menunjukkan bahwa variabel penilaian risiko adalah variabel yang paling berpengaruh dominan terhadap efisiensi penyaluran kredit.

Berdasarkan hasil uji koefisien determinasi pada Tabel 9 menunjukkan bahwa koefisien determinasi (R square) sebesar 0,857 atau 85,7 persen, angka ini dapat diartikan 85,7 persen tingkat efisiensi penyaluran kredit mampu dijelaskan oleh variabel pengendalian internal yang meliputi lingkungan pengendalian, penilaian risiko, informasi dan komunikasi, aktivitas pengendalian, dan pemantauan, sedangkan sisanya 14,3 persen dijelaskan oleh variabel lain diluar model regresi yang digunakan.

Hasil perhitungan uji $\mathrm{F}$ pada Tabel 9, diperoleh tingkat signifikansi sebesar 0,000 yang lebih kecil dari $a=0,05$, maka model regresi yang digunakan dianggap layak untuk digunakan.

Uji hipotesis (uji t) dilakukan untuk menguji pengaruh masing - masing variabel bebas yaitu pengendalian internal yang meliputi lingkungan pengendalian, penilaian risiko, aktivitas pengendalian, informasi dan komunikasi, dan pemantauan pada variabel terikat yaitu efisiensi penyaluran kredit di LPD se- 
Kecamatan Sukawati. Uji statistik dilakukan dengan membandingkan hasil nilai signifikansi dengan $a=0,05$.

Hipotesis pertama menyatakan bahwa lingkungan pengendalian berpengaruh positif pada efisiensi penyaluran kredit di LPD se-Kecamatan Sukawati. Berdasarkan Tabel 9 diperoleh nilai signifikansi t untuk uji variabel lingkungan pengendalian sebesar 0,002 lebih kecil dari 0,05 dan nilai koefisien regresi sebesar 0,229. Hal ini berarti bahwa lingkungan pengendalian berpengaruh positif pada efisiensi penyaluran kredit, sehingga hipotesis dalam penelitian ini diterima. Adanya pengaruh signifikan variabel lingkungan pengendalian dan efisiensi penyaluran kredit mengandung arti bahwa semakin baik lingkungan pengendalian yang diterapkan, maka akan meningkatkan efisiensi penyaluran kredit. Lingkungan pengendalian LPD dapat tercermin dari penerapan struktur organisasi LPD yang jelas, kesadaran karyawan LPD terhadap tugas dan tanggungjawabnya. Pengurus dan karyawan LPD juga telah menjalankan kegiatan operasional dengan baik sehingga pengendalian internal terutama pada penyaluran kredit dapat berjalan secara efektif.

Hasil penelitian ini juga sejalan dengan teori keagenan dimana teori ini mencerminkan tugas dan tanggungjawab yang jelas dari masing - masing karyawan sesuai dengan struktur organisasi yang telah ditetapkan. Penetapan tugas dan tanggungjawab ini akan berpengaruh terhadap kelangsungan usaha, dimana masing - masing karyawan harus fokus pada tugas dan tanggungjawabnya, sehingga dapat meningkatkan efisiensi penyaluran kredit. 
Hipotesis kedua menyatakan bahwa penilaian risiko berpengaruh positif pada efisiensi penyaluran kredit di LPD se-Kecamatan Sukawati. Berdasarkan Tabel 9 diperoleh hasil signifikansi uji t untuk variabel penilaian risiko sebesar 0,000 lebih kecil dari 0,05 dan nilai koefisien regresi sebesar 0,405. Hal ini berarti bahwa penilaian risiko berpengaruh positif pada efisiensi penyaluran kredit, sehingga hipotesis kedua dalam penelitian ini diterima. Adanya pengaruh signifikan variabel penilaian risiko dan efisiensi penyaluran kredit mengandung arti bahwa proses identifikasi terhadap risiko - risiko yang akan terjadi telah dilakukan dengan baik, sehingga baik untuk pengendalian risiko kredit macet. Penilaian risiko LPD dapat tercermin dari penerapan pengendalian internal dalam pemberian risiko LPD dimana selalu dilakukan analisis terhadap kemampuan debitur untuk membayar kreditnya.

Hasil penelitian ini sesuai dengan hasil penelitian Virnawan \& Putra (2014), Ekaulandari \& Dwirandra (2013), dan Gunadi et al. (2017) yang menyatakan bahwa penilaian risiko berpengaruh positif pada efisiensi penyaluran kredit. Penilaian risiko dapat ditingkatkan dengan melaksanakan proses analisis yang matang dalam memberikan kredit untuk mengurangi non performing loan. Hasil penelitian ini sejalan dengan teori keagenan dimana pihak LPD yang menyalurkan dana dalam bentuk krdit kepada debitur untuk dikelola sesuai dengan kepentingan debitur dan debitur harus dapat mengembalikan kredit tersebut kepada pihak LPD. Teori ini dapat terwujud dalam kontrak yang mengatur hak dan kewajiban dengan tetap memperhatikan keuntungan masing masing pihak. Kontrak ini akan optimal apabila agen (debitur) menjalan 
kewajibannya yaitu membayar kredit kepada principal (pihak LPD) sesuai dengan perjanjian yang telah disepakati.

Hipotesis ketiga menyatakan bahwa informasi dan komunikasi berpengaruh negatif pada efisiensi penyaluran kredit di LPD se-Kecamatan Sukawati. Berdasarkan Tabel 9 diperoleh hasil signifikansi uji t untuk variabel informasi dan komunikasi sebesar 0,002 lebih kecil dari 0,05 dan nilai koefisien regresi sebesar -0,154. Hal ini berarti bahwa informasi dan komunikasi berpengaruh negatif pada efisiensi penyaluran kredit, sehingga hipotesis ketiga dalam penelitian ini ditolak. Berdasarkan hasil statistik deskriptif menunjukkan bahwa variabel informasi dan komunikasi memiliki nilai terendah dan didukung juga oleh hasil tabulasi data terendah pada pernyataan nomor 3. Hal tersebut menunjukkan bahwa dokumen perjanjian kredit di LPD masih menemui kendala yang memberatkan salah satu atau kedua belah pihak sehingga perjanjian kredit tersebut belum memberi keyakinan pada pengguna informasi itu sendiri.

Hasil penelitian ini sesuai dengan hasil penelitian Sukadanayasa \& Suardikha (2016) dan Gunadi et al. (2017) informasi dan komunikasi yang terjalin pada LPD berjalan kurang efektif sehingga setiap orang belum mampu memahami perannya dalam sistem pengendalian internal, sebagaimana memahami aktivitas perseorangan terkait dengan pekerjaan orang lain.

Hipotesis keempat menyatakan bahwa aktivitas pengendalian berpengaruh positif pada efisiensi penyaluran kredit di LPD se-Kecamatan Sukawati. Berdasarkan Tabel 9 diperoleh hasil signifikansi uji t untuk variabel penilaian risiko sebesar 0,009 lebih kecil dari 0,05 dan nilai koefisien regresi sebesar 0,242. 
Hal ini berarti bahwa aktivitas pengendalian berpengaruh positif pada efisiensi penyaluran kredit, sehingga hipotesis keempat dalam penelitian ini diterima. Aktivitas pengendalian bernilai positif berarti bahwa semakin tinggi penerapan aktivitas pengendalian maka penyaluran kredit semakin efisien. Aktivitas pengendalian LPD tercermin dari kegiatan operasional LPD dan sistem pemberian kredit LPD yang telah dilaksanakan sesuai dengan prosedur yang diterapkan. Aktivitas pengendalian LPD juga meliputi kegiatan otorisasi yang tepat dalam transaksi kredit dan pemisahan tugas LPD. Pemisahan tugas LPD dilakukan untuk mengurangi peluang seseorang dalam melakukan kecurangan atau kesalahan menjalankan tugas serta meningkatkan efisiensi penyaluran kredit.

Hasil penelitian ini sejalan dengan hasil penelitian dari Virnawan \& Putra (2014), Ekaulandari \& Dwirandra (2013), dan Gunadi et al. (2017) yang menyatakan bahwa aktivitas pengendalian berpengaruh positif pada efisiensi penyaluran kredit. Hasil penelitian ini juga sesuai dengan teori agensi dimana dalam pengelolaan suatu lembaga keuangan harus dilakukan pemisahan tugas untuk menghindari terjadinya komflik kepentingan akibat ketidaksamaan tujuan dan hal ini akan menjadi peluang dalam melakukan berbagai kecurangan dalam pemberian kredit. Dengan demikian aktivitas pengendalian yang diterapkan dengan baik akan mengurangi tingkat kredit bermasalah.

Hipotesis kelima menyatakan bahwa pemantauan berpengaruh positif pada efisiensi penyaluran kredit di LPD se-Kecamatan Sukawati. Berdasarkan Tabel 9 diperoleh hasil signifikansi uji t untuk variabel pemantauan sebesar 0,027 lebih kecil dari 0,05 dan nilai koefisien regresi sebesar 0,199. Hal ini berarti bahwa 
pemantauan berpengaruh positif pada efisiensi penyaluran kredit, sehingga hipotesis kelima dalam penelitian ini diterima. Pemantauan merupakan yang terpenting dalam pengendalian internal penyaluran kredit. Pemantauan bernilai positif yang berarti bahwa pemantauan yang dilakukan secara rutin akan menurunkan tingkat kredit bermasalah dan meningkatkan efisiensi penyaluran kredit LPD. Pemantauan dalam LPD meliputi proses penilaian kualitas kinerja sepanjang waktu dan memastikan semuanya dijalankan seperti yang diinginkan dan disesuaikan dengan perubahan keadaan. Hal ini berarti bahwa semakin rutin pihak LPD dalam melakukan pemantauan atau pengawasan maka semakin rendah kredit bermasalah.

Pemantauan dilakukan untuk memberkan keyakinan apakah pengendalian internal telah dilakukan secara efektif atau tidak. Hasil penelitian ini sesuai dengan penelitian Suriadnya \& Sunarwijaya (2015), Febriani (2016), dan Gunadi et al. (2017) yang menyatakan pemantauan berpengaruh positif pada efisiensi penyaluran kredit. Pemantauan yang dilakukan dengan baik dapat menurunkan non performing loan dan meningkatkan efisiensi penyaluran kredit.

Hasil penelitian ini memberikan tambahan informasi mengenai pengaruh lingkungan pengendalian, penilaian risiko, informasi dan komunikasi, aktivitas pengendalian, dan pemantauan pada efisiensi penyaluran kredit. Bukti empiris yang diperoleh melalui penelitian ini yang menunjukkan bahwa lingkungan pengendalian, penilaian risiko, aktivitas pengendalian, dan pemantauan berpengaruh positif pada efiesiensi penyaluran kredit. Informasi dan komunikasi berpengaruh negatif pada efisiensi penyaluran kredit. 
Penelitian ini menunjukkan LPD se-Kecamatan Sukawati telah menerapkan dengan baik lingkungan pengendalian, penilaian risiko, aktivitas pengendalian, dan pemantauan yang membantu meningkatkan efisiensi penyaluran kredit LPD. Variabel informasi dan komunikasi belum diterapkan dengan baik karena hasil tabulasi data menunjukkan dokumen perjanjian kredit di LPD masih menemui kendala yang memberatkan salah satu atau kedua belah pihak sehingga perjanjian kredit tersebut belum memberi keyakinan pada pengguna informasi itu sendiri.

\section{SIMPULAN}

Variabel lingkungan pengendalian, penilaian risiko, aktivitas pengendalian, dan pemantauan berpengaruh positif pada efisiensi penyaluran kredit di LPD Kecamatan Sukawati, Kabupaten Gianyar. Hal ini menunjukkan bahwa semakin baik variabel - variablel tersebut yang diterapkan maka semakin meningkat efisiensi penyaluran kredit.

Variabel informasi dan komunikasi berpengaruh negatif pada efisiensi penyaluran kredit di LPD Kecamatan Sukawati, Kabupaten Gianyar. Hal ini menunjukkan informasi dan komunikasi yang terjalin pada LPD berjalan kurang efektif sehingga setiap orang belum mampu memahami perannya dalam sistem pengendalian internal, sebagaimana memahami aktivitas perseorangan terkait dengan pekerjaan orang lain. Komunikasi yang baik seharusnya diterapkan pada LPD sehingga memberikan keyakinan bahwa transaksi telah dicatat, telah 
diotorisasi dan telah dinilai dengan wajar sehingga menekan kredit macet serta meningkatkan efisiensi penyaluran kredit.

\section{REFERENSI}

Almilia, L. S., \& Herdinigtyas, W. (2005). Analisis Rasio Camel Terhadap Prediksi Kondisi Bermasalah pada Lembaga Perbankan Periode 2000 - 2002. Jurnal Akuntansi Dan Keuangan, 7(2), 131-147. https://doi.org/10.9744/jak.7.2.pp.\%20131-147

Ariesa, L., \& Berasategu, R. G. (2009). The Analysis Of Internal Controls On Revenue And Expenditure Cycle In PT. Levina. Journal of Applied Finance and Accounting, 1(2), 268-280.

Boynton, Johnson, \& Kell. (2009). Modern Auditing. Jakarta: Erlangga.

Ekaulandari, N. W. V., \& Dwirandra, A. A. N. . (2013). Pengaruh Penaksiran Risiko, Informasi dan Komunikasi, Aktivitas Pengendalian, Pemantauan, Lingkungan Pengendalian Pada Efektivitas Sistem Pemberian Kredit. EJurnal Akuntansi Universitas Udayana, 4(3), 585-604. Retrieved from https://ojs.unud.ac.id/index.php/Akuntansi/article/view/6380

Febriani, K. A. (2016). Pengaruh Komponen Struktur Pengendalian Internal Terhadap Efisiensi Penyaluran Kredit Pada Lembaga Perkreditan Desa (LPD) Di Kota Denpasar. Akuntansi Universitas Mahasaraswati.

Febrianti, M. (2012). Faktor-faktor Yang Memengaruhi Nilai Perusahaan pada Industri Pertambangan di Bursa Efek Indonesia. Jurnal Bisnis Dan Akuntansi, 14(2), 141-156.

Firdaus, R., \& Ariyanti, M. (2008). Manajemen Perkreditan Bank Umum. Bandung: Alfabeta.

Ghozali, I. (2012). Aplikasi Analisis Multivariatedengan Program IBM SPSS. 20 (6th ed.). Semarang: Universitas Diponegoro.

Gunadi, I. G. N. B., Imbayani, I. G. A., \& Putra, I. G. C. (2017). Efisiensi Penyaluran Kredit pada Lembaga Perkreditan Desa: Kajian Berdasarkan Komponen Struktur Pengendalian Internal. Jurnal Ilmu Manajemen (JUIMA), 7(1).

Halim, A. (2008). Auditing I (Dasar-dasar Audit Laporan Keuangan). Yogyakarta: AMD YKPM. 
Janvrin, D. J., Payne, E. A., Byrnes, P., Schneider, G. P., \& Curtis, M. B. (2012). The Updated COSO Internal Control-Integrated Framework: Recommendations and Opportunities for Future Research. Journal of Information Systems, 26(2), 189-213. https://doi.org/10.2308/isys-50255

Jensen, M. C., \& Meckling, W. H. (1976). Theory of the Firm: Managerial Behavior, Agency Costs and Ownership Structure Theory of the Firm: Managerial Behavior, Agency Costs and Ownership Structure. Journal of Financial Economics, 3(4), 305-360. https://doi.org/10.1016/0304405X(76)90026-X

Kasmir. (2008). Manajemen Perbankan (Revisi). Jakarta: Rajawali Press.

Mahsun, M. (2009). Pengukuran Kinerja Sektor Publik. Yogyakarta: BPFE.

Messier, W. ., S.M. Glover, \& Prawitt, D. F. (2006). Auditing and Assurance Services A Systematic Approach (Fourth). New York: McGrw-Hill Companies,Inc.

Pramesti, I. G. A. A., Budiartha, I. K., \& Rasmini, N. K. (2015). Pengaruh Kualitas Sistem Informasi Akuntansi Pada Profitabilitas LPD. E-Jurnal Ekonomi Dan Bisnis Universitas Udayana, 4(7), 443-457. Retrieved from http://ojs.unud.ac.id/index.php/Aku

RMP, M., Kamaliah, \& Nurmayanti, P. (2014). Faktor-Faktor Yang Mempengaruhi Net Interest Margin (Bank Go Publik Tahun 2008 S/D 2011). Jurnal Tepak Manajemen Bisnis, VI(3), 69-80.

Safitri, A. (2011). Analisis Efektivitas Struktur Pengendalian Internal Terhadap Kinerja Perkreditan Pada Bank Perkreditan Rakyat Kedung Arto di Kota Semarang. UDiNus Repository, (27 November 2015). Retrieved from http://eprints.dinus.ac.id/id/eprint/17239

Setyawan, K. M., \& Putri, I. G. A. M. A. D. (2013). Pengaruh Good Corporate Governance Terhadap Kinerja Keuangan Lembaga Perkreditan Desa Di Kecamatan Mengwi Kabupaten Badung. Jurnal Akuntansi Universitas Udayana, 5(2).

Suartana, I. W. (2009). Arsitektur Pengelolaan Risiko Pada Lembaga Perkreditan Desa (LPD). Bali: Udayana University Press.

Sugiyono. (2017). Metode Penelitian Kuantitatif, Kualitatif, dan R\&D. Bandung: Alfabeta.

Sukadanayasa, I. G., \& Suardikha, I. M. S. (2016). Pengaruh Komponen Pengendalian Intern Terhadap Keputusan Pemberian Kredit Pada Bank 
Perkreditan Rakyat Di Kabupaten Tabanan. E-Jurnal Akuntansi Universitas Udayana, 16(3), 1912-1937.

Suriadnya, I. K., \& Sunarwijaya, I. K. (2015). Pengaruh Komponen Struktur Pengendalian Internal Terhadap Efisiensi Penyaluran Kredit Pada Lembaga Perkreditan Desa (LPD) di Kota Denpasar. Jurnal Riset Akuntansi, 5(Desember), 2015.

Takahiro, S., \& Jia, P. (2012). Comparison of Internal Control Systems in Japan and China. International Journal of Business Administration, 3(1), 66-74. https://doi.org/10.5430/ijba.v3n1p66

Trisnawati, N. N. A. A., \& Wirakusuma, M. G. (2015). Pengaruh Kredit Yang Disalurkan Pada Hubungan Antara Dana Pihak Ketiga Dengan Profitabilitas. E-Jurnal Akuntansi Universitas Udayana, 11(2), 561-574. Retrieved from http://ojs.unud.ac.id/index.php/Aku

Virnawan, I. M. E., \& Putra, I. G. C. (2014). Efisiensi Penyaluran Kredit Pada Lembaga Perkreditan Desa (LPD) di Kecamatan Marga-Tabanan. Jurnal Ilmiah Akuntansi Dan Bisnis, 9(2), 101-110.

Wiradana, I. G. O., Sulindawati, N. L. G. E., \& Admadja, A. T. (2015). Analisis Penerapan Sistem Pengendalian Internal Terhadap Pemberian Kredit Di Lembaga Perkreditan Desa (Studi Empiris Lembaga Perkreditan Desa Poh Bergong). E-Journal S1 Ak Universitas Pendidikan Ganesha, 3(1). 